China, was called Nànwàng de lüchéng (Unforgettable Journey, 1957) and was followed by Jiǔ ge nürén jí qí tā (Nine Women, 1959), introducing the new China to Hong Kong. After coming to the United States, she published Ľ̌ Huìñng tōngxūnjí (Li Huiying's Writings, 1979); it was published in China in Chinese, as were all her books; this was followed by Shijiè buāxùlù (Sidelights on World Affairs, 1985), Ľ̌ Huìying tōngxūnjízēngdìngbèn (Expanded Edition of Li Huiying's Writings, 1988), and Biéle, 20 shijì (Farewell, Twentieth Century, 2001). She wrote profusely for Chinese periodicals, published in Hong Kong, mainland China, the United States, and the Chinese communities in a number of others nations.

$\mathrm{Li}$ was an extremely popular speaker, especially in Chinese, and was much praised for her style of writing in Chinese, which revealed her study of Chinese literature, poetry, and history. She received many awards, among which were Outstanding Hong Kong Businesswoman by the South China Morning Post (1962), Outstanding Member by the US-China People's Friendship Association (1981), and the first annual award by the Los Angeles-Guangzhou Sister City Association (1984). In 1999 she was made the first ever honorary reporter by the Xinmin Evening News, published in Shanghai and with the largest circulation of any daily paper in China (including the People's Daily). She was also honored with a plaque by the East Asian Studies Center at USC in 2003 and by being named woman of the year by Horizon Magazine in Hong Kong in January 2004, eleven months before her death.

$\mathrm{Li}$ attended many international conferences representing especially Chinese women and peace. In 1975, she debated Betty Friedan at the First International Women's Conference, held in Mexico City; Friedan represented the cynicism of women in America and $\mathrm{Li}$ the hopes for women which were being embedded in the new constitutions being written in the developing world. Later she joined in nominating Helen Foster Snow (wife of Edgar Snow) for the Nobel Peace Prize, for her peace efforts in the Chinese civil war, which she did not receive; she also helped nominate Kim Dae Jung, president of South Korea, for his efforts toward a peaceful Korean reunification, which he did receive.

Li will be remembered for her warm love for both her motherland and her adopted land of opportunity. She worked tirelessly for friendship between the two and for the peaceful inclusion of Taiwan in the China that was envisioned by Dr. Sun Yat-sen, but her emphasis was always on "peaceful" as the only really legitimate kind of reunification.

George OAkley Totten III University of Southern California

\title{
MANI KAMERKAR
}

(October 14, 1925-October 11, 2004)

Dr. (Mrs.) Mani Kamerkar was a lifelong teacher, chiefly in the Shreemati Nathibai Damodar Thackersey (SNDT) Women's Colleges of Mumbai. She served as principal of Nanavati College and after retirement worked on SNDT development 
and then for the Asiatic Society of Bombay as a vice-president. She continued to guide doctoral students and to make sure that her former students who were teachers had international conference experience; she also continued to extend help and encouragement to foreign scholars. She taught as a visiting professor at Agnes Scott College and at Carleton College. Her academic work focused on the social and political history of western India and included the British influence on Gujarat and the history of the Parsis. Most recent is her work on archeological evidence of Parsi history; she directed a study on the excavations in Sanjan and worked toward the restoration of the sacred Bahrot caves. She published forty-five articles. Her most recent book is From the Iranian Platean to the Shores of Gujarat: The Story of Parsi Settlements and Absorption in India, coauthored with Soonu Dhunjisha and published by the K. R. Cama Oriental Institute in 2002 .

\author{
ELEANOR ZELLIOT \\ Carleton College
}

\title{
FREDERICK W. MOTE
}

(June 2, 1922-February 10, 2005)

Frederick W. Mote, professor emeritus of East Asian Studies at Princeton University, died after a long illness in Denver, Colorado, at the age of eighty-two. Regarded even among leading scholars in Taiwan, Hong Kong, Singapore, and China as one of the twentieth century's preeminent students of traditional Chinese civilization, Professor Mote wrote, edited, and translated numerous books, scholarly articles, and essays on subjects ranging from classical Chinese philosophy to military history and from the study of great cities such as Suzhou and Nanjing to the ways in which poetry, painting, and other arts could be used to gain a fuller understanding of Chinese economic, social, and cultural history. Mote was one of a very small number of academic pioneers instrumental in transforming the study of China and East Asia in the United States from a neglected backwater at most colleges and universities to a mature field with high standards and a distinguished record of scholarly achievement. He effected this important change through his publications; his teaching at Princeton University and the University of Washington; and his years of service to organizations such as the Committee on Scholarly Communication with the People's Republic of China (of which he was a founding member), the Chinese Advisory Committee of the Modern Languages Association, the Inter-University Board for Chinese Language Studies in Taiwan (which he chaired from 1961 to 1964), the Committee on Studies of Chinese Civilization of the American Council of Learned Societies (which he chaired from 1974 to 1978), the editorial board of the journal Asia Major, the Smithsonian Council, and the Visiting Committee of the Freer Gallery of Art.

Mote enlisted in the United States Army Air Forces (USAAF) early in 1943. A Chinese-language course that he had taken during the summer of 1942 at George Washington University caused his superiors to transfer him to a military unit at Harvard University, where he participated in a special language program that was 